\title{
REVIEW
}

\section{Clinical review: Clinical management of new oral anticoagulants: a structured review with emphasis on the reversal of bleeding complications}

\author{
Alejandro Lazo-Langner*1,2, Eddy S Lang ${ }^{3}$ and James Douketis ${ }^{4}$
}

\begin{abstract}
New oral anticoagulants, including dabigatran, rivaroxaban, and apixaban, have been recently approved for primary and secondary prophylaxis of thromboembolic conditions. However, there is no clear strategy for managing and reversing their anticoagulant effects. We aimed to summarize the available evidence for clinical management and reversal of bleeding associated with new oral anticoagulants. Using a systematic review approach, we aimed to identify studies describing reversal strategies for dabigatran, rivaroxaban, and apixaban. The search was conducted using Medline, EMBASE, HealthSTAR, and grey literature. We included laboratory and human studies. We included 23 studies reported in 37 out of 106 potentially relevant references. Four studies were conducted in humans and the rest were in vitro and in vivo studies. The majority of the studies evaluated the use of prothrombinase complex concentrate (PCC), either activated or inactivated, and recombinant activated factor VII (rFVIla). Other interventions were also identified. Laboratory studies suggest that hemostatic parameters and bleeding might be partially or completely corrected by PCC for rivaroxaban better than dabigatran. Studies in humans suggest that PCC might reverse the effects of rivaroxaban better than dabigatran assessed by hemostatic tests. We were not able to locate studies evaluating the clinical efficacy of these agents. The best available evidence suggests that PCC (activated or inactivated) might be the best option for reversing new anticoagulants. Evidence for rFVIla is less compelling. There might be differences in the efficacy of reversing agents for different anticoagulants. Studies assessing the clinical efficacy of these reversal agents are urgently needed.
\end{abstract}

\section{Background}

Dabigatran etexilate (Pradaxa), rivaroxaban (Xarelto), and apixaban (Eliquis) are new oral anticoagulants (NOACs) that are approved in North America for reducing the risk of venous thromboembolism after hip or knee replacement and for stroke prevention in nonvalvular atrial fibrillation. In addition, rivaroxaban is approved for the treatment deep vein thrombosis without pulmonary embolism in Canada or deep vein thrombosis with or without pulmonary embolism in the US [1]. The key properties of these drugs are summarized in Table 1. Dabigatran directly inhibits both free and clot-bound thrombin, which impedes the conversion of fibrinogen to fibrin, thus preventing thrombus development [2]

\footnotetext{
*Correspondence: alejandro.lazolangner@|hsc.on.ca

'Department of Medicine, University of Western Ontario, 800 Commissioners Rd. East, Room A2-401, London, ON, Canada, N6A 5W9

Full list of author information is available at the end of the article
}

(Figure 1). Rivaroxaban and apixaban are selective direct inhibitors of activated factor X (FXa) and result in decreased activation of prothrombin to thrombin [3].

Until the approval of the NOACs, warfarin was the only orally administered anticoagulant available for use in all of the aforementioned indications. However, warfarin use is associated with several drawbacks, including its narrow therapeutic range, extensive drug and food interactions, and need for laboratory monitoring. Nevertheless, there is extensive experience regarding the clinical management of warfarin and its associated complications (in particular, bleeding), but this is not the case for NOACs. In the case of warfarin, the management of bleeding is well known; however, experience in the management of bleeding complications associated with NOACs is very limited and there are no available antidotes (whereas antidotes are available for warfarin). Therefore, in the case of NOAC-associated hemorrhage, treatment options are unclear and there is a need to provide evidence-based guidance on the management of these potentially life-threatening complications. This is 
Table 1. Characteristics of new oral anticoagulants

\begin{tabular}{|c|c|c|c|}
\hline & Dabigatran (Pradaxa) & Rivaroxaban (Xarelto) & Apixaban (Eliquis) \\
\hline \multicolumn{4}{|l|}{ Clinical indications and dosing ${ }^{\mathrm{a}}$} \\
\hline \multirow[t]{2}{*}{ Atrial fibrillation } & Normal renal function: 150 mg bid & $\mathrm{CrCl}>50 \mathrm{~mL} / \mathrm{min}: 20 \mathrm{mg}$ od & $\mathrm{CrCl} \geq 25 \mathrm{~mL} / \mathrm{min}: 5 \mathrm{mg}$ bid \\
\hline & $>75$ years: $110 \mathrm{mg} \mathrm{bid}$ & $\mathrm{CrCl} 30-49 \mathrm{~mL} / \mathrm{min}: 15 \mathrm{mg}$ od & $\begin{array}{l}\text { If } 2 \text { or more of the following: age } \geq 80 \text {, } \\
\text { weight } \leq 60 \mathrm{~kg} \text { or creatinine } \\
\geq 1.5 \mathrm{mg} / \mathrm{dL}: 2.5 \mathrm{mg} \text { bid }\end{array}$ \\
\hline $\begin{array}{l}\text { Deep vein thrombosis without } \\
\text { symptomatic pulmonary embolism } \\
\text { (Canada) }\end{array}$ & \multirow[t]{2}{*}{ Not approved } & $\begin{array}{l}\mathrm{CrCl}>50 \mathrm{~mL} / \mathrm{min}: 15 \mathrm{mg} \text { bid } \times \\
21 \text { days then } 20 \mathrm{mg} \text { od for at least } \\
\text { 3-6 months }\end{array}$ & \multirow[t]{2}{*}{ Not approved } \\
\hline $\begin{array}{l}\text { Deep vein thrombosis and } \\
\text { pulmonary embolism (US) }\end{array}$ & & $\begin{array}{l}\mathrm{CrCl} 30-49 \mathrm{~mL} / \mathrm{min}: 15 \mathrm{mg} \text { bid } \times \\
21 \text { days then } 15 \mathrm{mg} \text { od for at least } \\
3-6 \text { months }\end{array}$ & \\
\hline \multirow{2}{*}{$\begin{array}{l}\text { Venous thromboembolism } \\
\text { prophylaxis after total hip } \\
\text { replacement surgery (14-35 days) }\end{array}$} & $\begin{array}{l}\text { Normal renal function: } 220 \mathrm{mg} \text { od } \times \\
10 \text { days }\end{array}$ & \multirow[t]{2}{*}{$10 \mathrm{mg}$ od $\times 35$ days } & \multirow[t]{2}{*}{$2.5 \mathrm{mg}$ bid $\times 32-38$ days } \\
\hline & $\begin{array}{l}>75 \text { years or } \mathrm{CrCl} 30-50 \mathrm{~mL} / \mathrm{min} \text { : } \\
150 \mathrm{mg} \text { od } \times 10 \text { days }\end{array}$ & & \\
\hline \multirow{2}{*}{$\begin{array}{l}\text { Venous thromboembolism } \\
\text { prophylaxis after total knee } \\
\text { replacement surgery (14-35 days) }\end{array}$} & $\begin{array}{l}\text { Normal renal function: } 220 \mathrm{mg} \text { od } \times \\
28-35 \text { days }\end{array}$ & \multirow[t]{2}{*}{$10 \mathrm{mg} \mathrm{od} \times 14$ days } & \multirow[t]{2}{*}{$2.5 \mathrm{mg}$ bid $\times 10-14$ days } \\
\hline & $\begin{array}{l}>75 \text { years or } \mathrm{CrCl} 30-50 \mathrm{~mL} / \mathrm{min} \text { : } \\
150 \mathrm{mg} \text { od } \times 28-35 \text { days }\end{array}$ & & \\
\hline \multicolumn{4}{|l|}{ Pharmacologic characteristics } \\
\hline Mechanism of action & Direct thrombin (Flla) inhibitor & Direct factor Xa inhibitor & Direct factor Xa inhibitor \\
\hline \multirow[t]{3}{*}{ Clearance } & Renal 85\% & \multirow{2}{*}{$\begin{array}{l}\text { Renal } 66 \% \text { (active and unchanged } \\
\text { drug and inactive metabolites) }\end{array}$} & Renal 27\% \\
\hline & Biliary/Fecal 20\% & & \multirow[t]{2}{*}{ Biliary/Fecal 75\% (active drug) } \\
\hline & & Biliary/Fecal 33\% (active drug) & \\
\hline \multicolumn{4}{|l|}{ Half-life } \\
\hline $\begin{array}{l}\text { Normal renal function } \\
(\mathrm{CrCl}>80 \mathrm{~mL} / \mathrm{min})\end{array}$ & $\sim 13$ hours & 5-9 hours & $\sim 12$ hours \\
\hline $\begin{array}{l}\text { Mild renal impairment } \\
(\mathrm{CrCl} 50-80 \mathrm{~mL} / \mathrm{min})\end{array}$ & $\sim 15$ hours & 5-9 hours & $\sim 12$ hours \\
\hline $\begin{array}{l}\text { Moderate renal impairment } \\
(\mathrm{CrCl} 30-49 \mathrm{~mL} / \mathrm{min})\end{array}$ & $\sim 18$ hours & $11-13$ hours & 10-14 hours \\
\hline $\begin{array}{l}\text { Severe renal impairment } \\
(\mathrm{CrCl}<30 \mathrm{~mL} / \mathrm{min})\end{array}$ & Contraindicated & Contraindicated & Contraindicated $^{b}$ \\
\hline Onset of action (after oral intake) & $1-3$ hours & $1-4$ hours & 3-4 hours \\
\hline Food or alcohol interactions & None & None & None \\
\hline \multirow[t]{3}{*}{ Drug interactions } & $\begin{array}{l}\text { P-glycoprotein inhibitors }{ }^{c} \text { (increase } \\
\text { systemic exposure) }\end{array}$ & $\begin{array}{l}\text { P-glycoprotein inhibitors (increase } \\
\text { systemic exposure) }\end{array}$ & $\begin{array}{l}\text { P-glycoprotein inhibitorsc (increase } \\
\text { systemic exposure) }\end{array}$ \\
\hline & \multirow[t]{2}{*}{$\begin{array}{l}\text { P-glycoprotein inducers }{ }^{d} \text { (decrease } \\
\text { systemic exposure) }\end{array}$} & $\begin{array}{l}\text { P-glycoprotein inducers }{ }^{d} \text { (decrease } \\
\text { systemic exposure) }\end{array}$ & $\begin{array}{l}\text { P-glycoprotein inducers }{ }^{d} \text { (decrease } \\
\text { systemic exposure) }\end{array}$ \\
\hline & & $\begin{array}{l}\text { Strong CYP } 3 A 4 \text { inhibitors and } \\
\text { inducers }^{\mathrm{e}}\end{array}$ & Strong CYP $3 A 4$ inhibitors and inducers ${ }^{\mathrm{e}}$ \\
\hline
\end{tabular}

alndications and dosing are based on Canadian information unless otherwise stated. For indications and dosing in other jurisdictions, please consult local authorities. ${ }^{\mathrm{b}} \mathrm{Apixaban}$ is contraindicated in patients with a creatinine clearance $(\mathrm{CrCL})$ of less than $15 \mathrm{~mL} / \mathrm{min}$ or on dialysis, and there is very limited experience in patients with a $\mathrm{CrCl}$ of $15-24 \mathrm{~mL} / \mathrm{min}$, in whom no dosing recommendations exist. 'P-glycoprotein inhibitors include verapamil, dronedarone, quinidine, amiodarone, clarithromycin, ritonavir, saquinavir, cyclosporine, tacrolimus, ketoconazole, and other azole antifungals. ${ }^{\mathrm{dP}}$-glycoprotein inducers include rifampicin, carbamazepine, Saint John's Wort, and tenofovir. eStrong CYP $3 A 4$ inhibitors include ketoconazole, voriconazole, posaconazole, and ritonavir. Fluconazole is a moderate CYP $3 A 4$ inhibitor and may be used with caution. Strong CYP $3 A 4$ inducers include rifampicin, phenytoin, carbamazepine, and phenobarbitone. bid, twice daily; CYP $3 A 4$, cytochrome P450 $3 A 4$ enzyme; od, once daily. Adapted from [1-3,17-19,57-61]. 


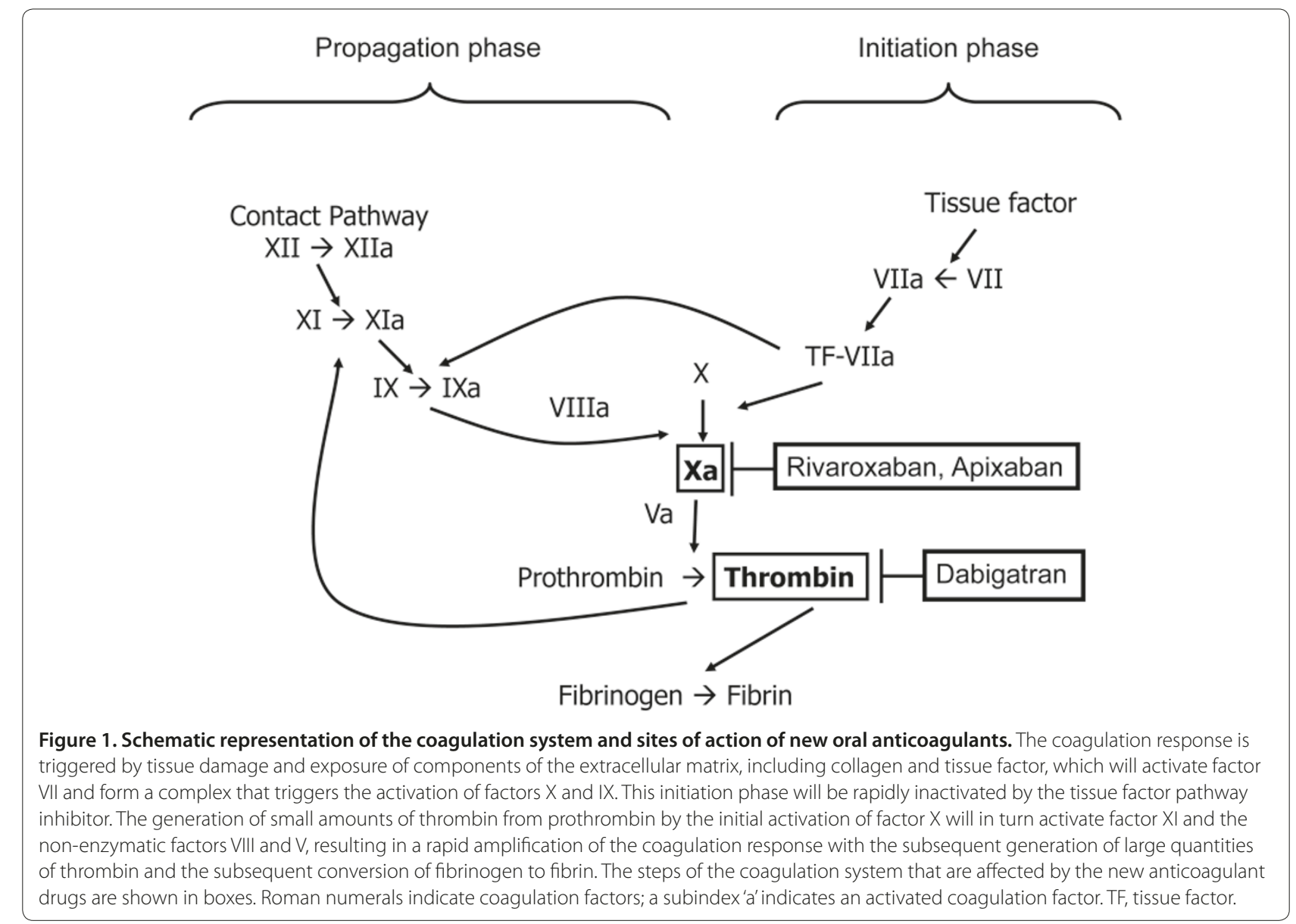

an urgent need because of the rapid uptake of NOACs in clinical practice, which will undoubtedly carry an increment in NOAC-associated bleeding. Therefore, because of the aforementioned reasons and the uncertainty about best practices, we conducted - in concert with clinical guide development for the Thrombosis Interest Group of Canada [4] - a review of the literature focusing on the management of bleeding associated with NOACs, the results of which are included herein.

\section{Clinical considerations in the management of new oral anticoagulants}

Hemostasis is a cautiously balanced process that teeters between thrombus formation and degradation and that consists of a series of enzyme-mediated reactions in which thrombin plays a central role (Figure 1). A basic understanding of the physiology of the hemostatic system might help when considering the selection of a reversal agent. It is theoretically possible that an agent such as activated prothrombinase complex concentrate (aPCC) is a better option when treating bleeding in patients who are receiving dabigatran, because it might provide a more efficient activation of the coagulation cascade, although it is also possible that if dabigatran is still present in plasma, it could neutralize the newly generated thrombin. In the case of rivaroxaban, it is also conceivable that PCC or aPCC might be effective since they would bypass the effect of FXa inhibition. However, it should be underscored that these considerations remain theoretical and are clinically unproven. It is also possible that pro-hemostatic agents lessen NOAC-related bleeding by overcoming the inhibitory effect of these drugs by means of providing massive amounts of factors II and X, either active or inactive.

In general, it should be recognized that pro-hemostatic agents are not antidotes to NOACs and do not affect the ongoing inhibitory effect of these drugs on factors IIa and Xa. Furthermore, it should be noted that previous studies in patients with intracerebral hemorrhage have suggested that, although pro-hemostatic agents can limit the extent of bleeding, their effect on mortality and disability appears minimal [5]. It should also be recognized that there is a small but clinically important risk when administering these agents as their use has been associated with an increased risk for venous and arterial thrombosis [6-10]. 
Blood products such as cryoprecipitate and fresh frozen plasma are unlikely to result in a clinically significant reversal. We were unable to find evidence supporting the use of anti-fibrinolytic agents such as aminocaproic and tranexamic acid. A number of new agents are currently in different phases of development. They include monoclonal antibodies and small molecules with specific affinity for the NOACs [11-13]. Clinical studies are eagerly awaited.

A number of practical considerations must be made when managing bleeding in patients on anticoagulants. It is necessary to understand the two different types of bleeding events often reported in the literature evaluating anticoagulants for different indications. A major bleed is usually defined as a fatal or symptomatic event that involves a critical site (intracranial, intraspinal, intraocular, retroperitoneal, intra-articular, pericardial, or intramuscular with compartment syndrome) or causes a hemoglobin level decrease of $20 \mathrm{~g} / \mathrm{L}$ or more within 24 hours or results in transfusion of more than two units of packed red blood cells. The most common sites of major bleeding are gastrointestinal (approximately 80\% of all bleeds), genitourinary, intracranial (including subdural, intracerebral (worst prognosis: $45 \%$ to $50 \%$ case fatality) [14,15], and subarachnoid), and soft tissue and intra-articular, which are typically traumatic. In contrast, minor bleedings are those that may require medical attention but, in general, do not require transfusion or hospitalization, are usually self-limiting, and do not require interruption of anticoagulant medication, although this could be necessary in cases of non-self-limiting events.

In the case of patients requiring an invasive procedure, temporary interruption of NOACs might be considered, but this should be individualized according to the type of procedure required. It should be remembered that NOACs have much shorter half-lives than warfarin (38 to 42 hours): dabigatran (11 to 17 hours), rivaroxaban (5 to 9 hours), and apixaban (9 to 12 hours). Thus, their anticoagulant effects may be reduced by over $75 \%$ within 24 to 36 hours of the last NOAC dose, after two half-lives have elapsed. Thus, even if coagulation tests are normal, elective procedures should not be performed until at least 24 to 36 hours (or longer in renal dysfunction) after discontinuation. Paradoxically, however, their short halflives might put the patients at a higher risk of thrombosis in the case of interruptions, as was suggested by the slight increase in thrombotic events in patients enrolled in the ROCKET AF trial when transitioning from rivaroxaban to warfarin at the end of the study, although this remains largely a theoretical concern [16].

In the case of patients with kidney disease, dose reductions are required in patients with a creatinine clearance $(\mathrm{CrCl})$ of 30 to $50 \mathrm{~mL} / \mathrm{min}$ because renal impairment prolongs the half-lives of NOACs, especially dabigatran. The use of NOACs is contraindicated in patients with a $\mathrm{CrCl}$ of less than $30 \mathrm{~mL} / \mathrm{min}$ in the case of dabigatran or a $\mathrm{CrCl}$ of less than $15 \mathrm{~mL} / \mathrm{min}$ for rivaroxaban and apixaban $[2,17,18]$. For patients with a $\mathrm{CrCl}$ of between 15 and $30 \mathrm{~mL} / \mathrm{min}$, no clear dosing recommendations exist. In bleeding patients receiving dabigatran, hemodialysis may be considered in cases of acute renal failure and laboratory evidence of an excessive anticoagulant effect since $80 \%$ of dabigatran is not plasma-bound. There is no available information for rivaroxaban or apixaban in this regard, although owing to their high protein binding, dialysis is unlikely to be very effective. One study showed that hemodialysis removes $62 \%$ to $68 \%$ of drug after a single $50 \mathrm{mg}$ dabigatran dose in patients with end-stage renal disease [19]. Another study suggests that dabigatran could be removed with the use of dialysis and charcoal hemoperfusion columns [20]. However, it is not known whether the removal of dabigatran by dialysis results in better bleeding control clinically. Finally, NOACs should be avoided in patients with moderate-to-severe liver dysfunction because of the lack of data in such patients.

Concomitant use of P-glycoprotein and CYP3A4 inhibitors (for example, azole antifungals such as ketoconazole) or inducers (for example, rifampicin and antiepileptics) may increase or decrease both drugs' anticoagulant effect, and their concurrent use is contraindicated (Table 1).

Finally, caution should be exerted when interpreting coagulation tests since all NOACs may alter common coagulation laboratory tests (Table 2). Although routine coagulation tests generally are not useful in evaluating the degree of anticoagulation in patients receiving NOACs, there is some evidence that, in a bleeding patient, the activated partial thromboplastin time (aPTT) may be useful in determining anticoagulant activity. Lindahl and colleagues [21] demonstrated that a prolonged aPTT of greater than 90 seconds and a prolonged quick prothrombin time (PT) may indicate overdosing or accumulation of dabigatran. However, it is very important to note that a normal aPTT or international normalized ratio result may not exclude the presence of clinically relevant levels of dabigatran and other NOACs. In addition, fibrinogen concentration can be falsely low in patients receiving dabigatran and this may lead to the unnecessary use of blood products such as cryoprecipitate [21]. Finally, although it has been noted that a normal thrombin time may indicate a lack of dabigatran activity, this test is extremely sensitive to very small amounts of the drug, rendering it unsuitable for clinical use. Owing to their predictable pharmacokinetic and pharmacodynamic profiles, NOACs do not require routine laboratory monitoring, but this does not preclude the need to monitor specific coagulation-related conditions 
Table 2. Effects of new anticoagulants on common coagulation tests

\begin{tabular}{|c|c|c|}
\hline Test & Dabigatran etexilate & Rivaroxaban or apixaban \\
\hline Activated partial thromboplastin time & Prolongation, variation among reagents & Prolongation, variation among reagents \\
\hline Prothrombin time (Quick method) ${ }^{\mathrm{a}}$ & Prolongation & Prolongation \\
\hline Prothrombin time (Owren method) ${ }^{\mathrm{a}}$ & Prolongation & Prolongation \\
\hline Fibrinogen (Clauss method) & Moderate to marked underestimation & Minimal effect \\
\hline Thrombin time & Marked prolongation & Minimal effect \\
\hline Hemoclot thrombin inhibitor assay & Prolongation & Not applicable \\
\hline International normalized ratio (point-of-care) & Elevation & Elevation? ${ }^{\mathrm{b}}$ \\
\hline Activated factor $X$ (FXa) activity & Minimal effect & Marked overestimation \\
\hline HepTest assay for monitoring heparin in plasma and whole blood & Not applicable & Marked, dose-dependent overestimation \\
\hline
\end{tabular}

aThere is significant variability in prothrombin time and international normalized ratio (INR) prolongation, depending on the reagents used and the time of administration of the drug. INR results might be elevated, ranging from 1.2 to more than 3.0 . ${ }^{b}$ No available information. Adapted from $[2,17,21,56,62-69]$.

related to bleeding complications or changes in bleeding risk factors such as renal function.

\section{Management of bleeding associated with new oral anticoagulants}

To evaluate the interventions so far tested for managing bleeding in patients taking NOACs, we used a structured approach. We aimed to retrieve randomized controlled trials, cohort studies, case control studies, case seriescase reports (including self-poisoning), or studies conducted in animal models or in vitro. To be considered for inclusion, a study had to propose an intervention to reverse the anticoagulant effect of the drugs of interest and measure either clinical or laboratory indices of bleeding.

The search was conducted in November 2012 by using the exploded terms rivaroxaban, dabigatran, and apixaban and the textwords 'reverse' or 'reversal'. The search was conducted by using the OVID interface in the following electronic databases: MEDLINE, EMBASE, and Healthstar. The search was restricted to articles written in English or French. The retrieved references were assessed for possible inclusion on the basis of the evaluation of the title and the abstract (or the full text if no abstract was available). Letters to the editor, review articles, editorials, and commentaries were excluded. Grey literature was considered, and we included the electronic versions of the abstracts of the following major international meetings: the International Society on Thrombosis and Haemostasis (1999 to 2011) and the American Society of Hematology (1999 to 2012). In addition, the reference lists of the retrieved journal articles were reviewed to locate additional studies of potential interest. The search was limited to articles published after 1996 since no information on these drugs was available prior to this date.

Potentially relevant studies were selected by one author and checked for accuracy by a second author. Owing to the heterogeneous nature of the studies included and to the lack of validated scales to assess the quality of the study designs included, we did not perform a quality assessment. Reports were divided into the following categories: (a) in vitro or in vivo studies (or both) in animal models and (b) studies in humans. Outcome was the effectiveness or potential effectiveness of the proposed interventions to revert NOACs. Owing to the heterogeneity among the studies, a formal meta-analysis was not conducted.

The search identified 106 potentially relevant references, of which 35 were included in the final review. Two additional references were identified through the review of reference lists. Excluded references included two mechanistic studies and one letter, whereas the rest were reviews. One additional study was excluded because it did not provide sufficient information [22]. We identified 23 studies reported in 37 references [11-13,20,23-55]. Nine studies were reported in more than one reference, and only five studies have been published in full, whereas the rest have been reported only in conference abstracts. Reversal of apixaban, dabigatran, and rivaroxaban has been evaluated in two, nine, and eight studies, respectively. Four studies have evaluated reversal of both rivaroxaban and dabigatran administered to human subjects, and only one has evaluated the administration of the proposed reversal agent to healthy volunteers. Nine studies included the evaluation of an in vivo model of bleeding in animals, whereas all studies evaluated different hemostatic parameters. The interventions evaluated included recombinant human activated factor VII (rFVIIa) (NovoSeven), four-factor prothrombinase complex (PCC) (Beriplex, Octaplex, Kaskadil, Cofact, and Kanokad), activated prothrombinase complex (aPCC) (FEIBA), fibrinogen concentrate, fIX/fX concentrate and fresh frozen plasma (FFP), high-purity FX concentrate, activated charcoal hemoperfusion, hemodialysis, an antidabigatran antibody/Fab fragment, and a recombinant 
reconstructed mutant factor Xa (r-Antidote, PRT064445). The 23 included studies are summarized in Table 3.

General principles should be observed for managing bleeding, including resuscitation, bleeding source control, drug cessation, and appropriate use of blood products. Activated charcoal can be considered if the offending drug was taken within two hours [56]. In the case of life-threatening or intracranial bleeding, the use of pro-hemostatic agents should be considered. Table 4 summarizes the currently available information regarding the reversal of NOACs, all of which is based on limited studies and should be considered low-quality. The best evidence so far comes from four studies in healthy volunteers who were receiving NOACs. The first study included healthy volunteers to whom rivaroxaban $(20 \mathrm{mg}$ twice a day) or dabigatran (150 mg twice a day) was administered for 2.5 days, after which they received a single dose of $50 \mathrm{IU} / \mathrm{kg}$ of four-factor (II, VII, IX, X) PCC, and its effects on PT, aPTT, thrombin time (TT), ecarin clotting time (ECT), and endogenous thrombin potential (ETP) were evaluated [26]. The study used Cofact, an agent available in Europe, but other similar four-factor PCCs (such as Octaplex or Beriplex) are available. The study showed that in subjects receiving rivaroxaban, both the PT and the ETP corrected to normal levels after administration of the PCC. In contrast, in patients receiving dabigatran, there were no corrections in the aPTT, ECT, ETP, or TT. In three other studies including healthy volunteers, participants received one or two doses of rivaroxaban $(20 \mathrm{mg})$ or dabigatran $(150 \mathrm{mg})$, and samples were obtained at different times after administration [33]. To test the ex vivo effect of pro-hemostatic agents, patients' samples were incubated with different concentrations of recombinant activated factor VII (rFVIIa, Novoseven), four-factor PCC (Kanokad, available in Europe; Beriplex; and Cofact), and activated fourfactor PCC (aPCC) (FEIBA; similar to four-factor PCC but with a more rapid effect because of the presence of 'activated' clotting factors). Coagulation was evaluated by measuring thrombin generation and other tests. The results of the studies showed that overall aPCC achieved the best correction of the coagulation parameters after rivaroxaban and dabigatran administration. Less efficient corrections were achieved with PCC and rFVIIa. Interestingly, one study suggested that lower doses of FEIBA might also be effective [33].

Bleeding has been assessed in some studies in animal models. A study evaluating the effects of rFVIIa and PCC in a rabbit bleeding model failed to show reversal of rivaroxaban-induced bleeding in spite of improvement in laboratory parameters [29]. However, other studies have reported reduced bleeding time in animal models of rivaroxaban-induced bleeding after administration of FEIBA [31,39]. In the case of dabigatran, animal models suggest that PCC, FEIBA, and rFVIIa could reduce bleeding $[41,43,46]$. There are other agents, such as threefactor (II, IX, X) PCC (currently used in the US), but evidence supporting their use in bleeding patients receiving NOACs is lacking and their use cannot be supported on the basis of currently available evidence. Perhaps the most significant in vivo animal study was published by Zhou and colleagues [46], who evaluated the effect of rFVIIA and PCC in an animal model of intracerebral bleeding in mice receiving dabigatran. The authors found that PCC at a dose of $100 \mathrm{IU} / \mathrm{kg}$ decreased the size and deterred the progression of the intraparenchymal hematoma and resulted in a lower mortality in the treated animals. Finally, only one study has described the experience with bleeding events in trials evaluating dabigatran for different indications [22]. The study reviewed 1,121 reports of major bleeding events and found that patients receiving dabigatran who developed major bleeding were older, had a lower creatinine clearance, and had more concurrent use of antiplatelet agents than those receiving warfarin. However, only nine patients received PCCs and two received rFVIIA, but no details were available at the time of review, and nothing can be extrapolated to the clinical scenario on the basis of the available information.

Finally, it should be re-emphasized that all information on clinical management should be considered low-quality on the basis of currently available data. When considering the use of these reversal agents, clinicians should very carefully consider the trade-off between benefits and potential risk.

\section{Conclusions}

In spite of the emerging information, there is still a considerable lack of evidence to inform clinical practice, and most of the recommendations are based on expert opinion and interpretation of available evidence. Whereas experience today suggests that in the case of a catastrophic event such as an intracerebral bleeding the use of reversal agents is unlikely to result in major clinical benefit, such agents still have a role in the case of patients requiring urgent surgical interventions which are potentially life-saving. The overall evaluation of the limited available studies suggests that the agents most likely resulting in benefit are PCC and aPCC but evidence for rFVIIa is less consistent. However, it is essential to note that no clinical experience is available to date and that all studies have used surrogate measures such as coagulation-based assays of hemostatic function or animal models. The actual effect of these agents in patients with bleeding events remains to be determined. In addition, the existing literature suggests that correction in hemostatic parameters does not necessarily correlate with an improvement in actual bleeding, and the currently available evidence is still confusing because of 
Table 3. Published studies evaluating interventions for the reversal of new oral anticoagulants

\begin{tabular}{|c|c|c|c|c|}
\hline $\begin{array}{l}\text { Study } \\
\text { (Reference) }\end{array}$ & $\begin{array}{l}\text { Anticoagulant(s) } \\
\text { evaluated }\end{array}$ & Reversal agent(s) & $\begin{array}{l}\text { Study design/ } \\
\text { Hemostatic assessment }\end{array}$ & Outcome \\
\hline \multicolumn{5}{|c|}{ In vitro studies and in vivo studies in animal models } \\
\hline \multirow[t]{3}{*}{ Escolar et al. [50] } & \multirow[t]{3}{*}{ Apixaban } & rFVIla $(270 \mu \mathrm{g} / \mathrm{kg})$ & \multirow{3}{*}{$\begin{array}{l}\text { In vitro study in health donor } \\
\text { samples spiked with apixaban } \\
\text { at a concentration of } 200 \mathrm{ng} / \mathrm{mL} \\
\text { assessing TG and TE. Additional } \\
\text { studies assessed hemostasis under } \\
\text { flow conditions. }\end{array}$} & \multirow{3}{*}{$\begin{array}{l}\text { TG parameters were variably improved in } \\
\text { order of efficacy by PCC, aPCC, and rFVIlla. } \\
\text { TE parameters were corrected in order } \\
\text { of efficacy by rFVIla, aPCC, and PCC. Flow } \\
\text { studies (resembling more closely a bleeding } \\
\text { situation) showed improvements in order of } \\
\text { efficacy by rFVIla, PCC, and aPCC. }\end{array}$} \\
\hline & & aPCC (75 IU/kg) & & \\
\hline & & PCC (50 IU/kg) & & \\
\hline
\end{tabular}

$\begin{array}{lll}\text { Martin et al. [34-36] } & \text { Apixaban } & \begin{array}{l}\text { rFVIIA, PCC, fibrinogen } \\ \text { concentrate. Doses not } \\ \text { reported. }\end{array} \\ & & \\ \text { Chan et al. [23] } & \text { Dabigatran } & \text { rFVIla }(150 \mu \mathrm{g} / \mathrm{kg}) \\ & & \text { aPCC (FEIBA VH, } 100 \mathrm{IU} / \mathrm{kg}) \\ & & \text { PCC (Beriplex) } \\ \text { Hoffman et al. [55] } & \text { Dabigatran } & 0.25-2.0 \mathrm{IU} / \mathrm{mL})\end{array}$

Rabbit in vivo bleeding model (hepatosplenic section) assessing $\mathrm{BT}, \mathrm{PT}, \mathrm{TE}, \mathrm{TG}$, and blood loss. Apixaban dose was not reported.

All agents improved laboratory parameters but did not reduce blood loss.

In vitro study using healthy donor samples spiked with dabigatran $150 \mathrm{ng} / \mathrm{mL}$ assessing TE

Both agents improved TE clot initiation time. aPCC achieved a more potent correction than rFVlla.

In vitro studies in human plasma spiked with dabigatran 189-944 ng/mL assessing TG

Activated charcoal perfusion In vitro and in vivo (pig model) and hemodialysis assessment of Absorba 300C activated charcoal filter or Polyflux $140 \mathrm{H}$ hemodialysis filter. Dabigatran tested in porcine whole blood at a concentration of $1,000 \mathrm{ng} / \mathrm{mL}$.

$\begin{array}{ll}\text { Pragst et al. [40] Dabigatran } & \text { PCC (Beriplex P/N) 20, 35, or } \\ & 50 \mathrm{IU} / \mathrm{kg}\end{array}$

Rabbit in vivo bleeding model (renal incision) assessing blood loss and time to hemostasis after dabigatran $0.4 \mathrm{mg} / \mathrm{kg}$

Toth et al. [48] Dabigatran

Anti-dabigatran humanized Fab $(30,90,175 \mathrm{mg} / \mathrm{kg})$

In vivo model in Rhesus monkeys receiving $12 \mathrm{mg} / \mathrm{kg}$ per day $x$ 4 days. Coagulation activity was assessed by dilute TT.

Van Ryn et al. (a) Dabigatran

PCC (Beriplex $35 \mathrm{IU} / \mathrm{kg}$ )

$[41,43,44]$

PCC (Octaplex $40 \mathrm{IU} / \mathrm{kg}$ )

Activated PCC (FEIBA

$100 \mathrm{IU} / \mathrm{kg})$

Rat in vivo bleeding model (tail cut) assessing time to hemostasis, aPTT, TT, PT, ECT, diluted TT, and Hemoclot. Dabigatran was

rFVIla (Novoseven $0.5 \mu \mathrm{g} / \mathrm{kg}$ ) administered at $30 \mathrm{mg} / \mathrm{kg}$.

PCC corrected some parameters in the TG assay.

Activated charcoal perfusion resulted in near-complete removal of dabigatran but showed saturation (maximum binding capacity $\sim 30 \mathrm{mg}$ ). Hemodialysis with flows achieved similar results.

Dose-dependent reduction of blood loss and time to hemostasis. Blood loss normalized at a dose of $50 \mathrm{IU} / \mathrm{kg}$.

Complete correction of TT at all 3 doses.

Anti-dabigatran antibody and Fab fragment

In vitro study in human plasma and rats ex vivo using diluted TT. In vivo rat tail bleeding model. Dabigatran was administered at $30 \mathrm{mg} / \mathrm{kg}$.

$\begin{array}{lll}\text { Van Ryn et al. (c) Dabigatran } & \begin{array}{l}\text { Activated charcoal } \\ \text { hemoperfusion }\end{array}\end{array}$

Zhou et al. [46] Dabigatran
PCC (Beriplex P/N; 50 and $100 \mathrm{IU} / \mathrm{kg})$

rFVlla (NovoSeven: $8.0 \mathrm{mg} / \mathrm{kg})$

FFP (murine, $200 \mu \mathrm{L} / \mathrm{kg}$ )
In vitro assessment of Adsorba cartridge. Dabigatran tested in bovine whole blood at a concentration of $1,000 \mathrm{ng} / \mathrm{mL}$.

In vivo and ex vivo study in mice receiving dabigatran at $2.25,4.5$, and $9.0 \mathrm{mg} / \mathrm{kg}$ assessing tail vein bleeding time and intracerebral hemorrhage volume and expansion (intrastriatal collagenase injection model)
All agents tested completely corrected prolongation of BT up to 2 hours.

$\mathrm{TT}$, aPTT, and ECT remained prolonged after all four agents.

PT was reversed to baseline with all agents.

In vitro studies showed rapid inhibition of dabigatran. BT in rat tail bleeding model was fully corrected.

Activated charcoal hemoperfusion resulted in near-complete removal of dabigatran.

At $9.0 \mathrm{mg} / \mathrm{kg}$ of dabigatran PCC (50 and $100 \mathrm{lU} / \mathrm{kg}$ ) but not rFVlla reduced intracerebral hematoma growth and mice mortality. FFP had an inconsistent beneficial effect on hematoma size reduction but not on mortality at lower dabigatran doses. PCC reduced tail vein $B T$ more effectively at a dose of $100 \mathrm{IU} / \mathrm{kg}$. 
Table 3. Continued

\begin{tabular}{|c|c|c|c|c|}
\hline $\begin{array}{l}\text { Study } \\
\text { (Reference) }\end{array}$ & $\begin{array}{l}\text { Anticoagulant(s) } \\
\text { evaluated }\end{array}$ & Reversal agent(s) & $\begin{array}{l}\text { Study design/ } \\
\text { Hemostatic assessment }\end{array}$ & Outcome \\
\hline \multirow[t]{2}{*}{ Godier et al. [27-29] } & \multirow[t]{2}{*}{ Rivaroxaban } & rFVIla $(150$ mg/kg) & \multirow{2}{*}{$\begin{array}{l}\text { Rabbit in vivo bleeding model } \\
\text { (hepatosplenic section) assessing } \\
\text { BT, TE, TG, and blood loss. } \\
\text { Rivaroxaban was administered at } \\
5 \mathrm{mg} / \mathrm{kg} \text {. }\end{array}$} & \multirow{2}{*}{$\begin{array}{l}\text { rFVIla corrected BT but not blood loss. PCC } \\
\text { did not correct BT or blood loss. PCC and } \\
\text { rFVlla decreased aPTT and TE clotting time. }\end{array}$} \\
\hline & & PCC (Kaskadil 40 IU/kg) & & \\
\hline \multirow[t]{2}{*}{ Gruber et al. [30,31] } & \multirow[t]{2}{*}{ Rivaroxaban } & $\begin{array}{l}\text { rFVlla (NovoSeven; } \\
210 \mu \mathrm{g} / \mathrm{kg} \text { ) }\end{array}$ & \multirow{2}{*}{$\begin{array}{l}\text { In vivo study in baboons receiving } \\
\text { rivaroxaban (IV bolus } 0.6 \mathrm{mg} / \mathrm{kg} \\
\text { followed by continued infusion } \\
0.6 \mathrm{mg} / \mathrm{kg} \text { per hour) assessing PT, } \\
\mathrm{TE} \text {, and BT }\end{array}$} & \multirow[t]{2}{*}{$\begin{array}{l}\text { aPCC reduced PT and normalized BT. fVIla } \\
\text { reduced but not fully corrected BT and PT. }\end{array}$} \\
\hline & & aPCC (FEIBA; 50 IU/kg) & & \\
\hline \multirow[t]{2}{*}{ Hollenbach et al. [53] } & \multirow[t]{2}{*}{ Rivaroxaban } & $\begin{array}{l}\text { r-Antidote (PRT064445) } \\
\text { (76 mg/rabbit) }\end{array}$ & \multirow{2}{*}{$\begin{array}{l}\text { In vivo rabbit liver laceration model } \\
\text { assessing blood loss, anti-fXa } \\
\text { activity, PT, and aPTT. Rivaroxaban } \\
\text { was given at } 1 \mathrm{mg} / \mathrm{kg} \text {. }\end{array}$} & \multirow{2}{*}{$\begin{array}{l}\text { r-Antidote (PRT064445) reduced blood } \\
\text { loss anti-XXa activity, PT, and aPTT. rFVIla } \\
\text { improved PT and aPTT but did not decrease } \\
\text { blood loss. }\end{array}$} \\
\hline & & rFVIla $(150$ mg/kg) & & \\
\hline Keller et al. [32] & Rivaroxaban & rFVlla 90 and $180 \mu \mathrm{g} / \mathrm{kg}$ & $\begin{array}{l}\text { In vitro study using healthy donor } \\
\text { samples spiked with rivaroxaban } \\
800,2,000 \text {, or } 5,000 \mathrm{ng} / \mathrm{mL} \\
\text { assessing TE }\end{array}$ & $\begin{array}{l}\text { Both dosages improved TE parameters at all } \\
\text { levels of rivaroxaban. }\end{array}$ \\
\hline Lloyd et al. [47] & Rivaroxaban & $\begin{array}{l}\text { High-purity factor } X \\
\text { concentrate }(1,2.5 \text {, and } \\
5 \mathrm{IU} / \mathrm{mL})\end{array}$ & $\begin{array}{l}\text { In vitro study using commercial } \\
\text { rivaroxaban calibration plasmas } \\
\text { spiked with } \mathrm{fX} \text { assessing PT }\end{array}$ & $\begin{array}{l}\text { fX reduced but not completely corrected PT. } \\
\text { No dose-response was observed. }\end{array}$ \\
\hline Lu et al. [11,12] & Rivaroxaban & $\begin{array}{l}\text { r-Antidote (PRT064445) } \\
(0.96 \mathrm{mg} / \text { mouse) }\end{array}$ & $\begin{array}{l}\text { In vitro and ex vivo studies in } \\
\text { mouse, rat, and human plasma } \\
\text { assessing anti-fXa activity and TG. } \\
\text { Blood loss assessed in a mouse tail } \\
\text { transection model. Rivaroxaban } \\
\text { was administered at } 50 \mathrm{mg} / \mathrm{kg} .\end{array}$ & $\begin{array}{l}\text { r-Antidote (PRT064445) decreased blood } \\
\text { loss, anti-fXa activity and whole blood INR. }\end{array}$ \\
\hline
\end{tabular}

\begin{tabular}{|c|c|c|c|}
\hline \multirow[t]{3}{*}{ Olesen et al. [37] } & \multirow[t]{3}{*}{ Rivaroxaban } & $\mathrm{rFVIla} \mathrm{(1.0} \mathrm{and} 2.0 \mu \mathrm{g} / \mathrm{mL})$ & \multirow{3}{*}{$\begin{array}{l}\text { In vitro study in health donor } \\
\text { samples spiked with rivaroxaban } \\
\text { at a concentration of } 1.33 \mu \mathrm{g} / \mathrm{mL} \\
\text { assessing TE }\end{array}$} \\
\hline & & PCC (0.29 and $0.58 \mathrm{IU} / \mathrm{mL})$ & \\
\hline & & $\begin{array}{l}\text { flX/fX concentrate }(0.29 \text { and } \\
0.58 \mathrm{IU} / \mathrm{mL})\end{array}$ & \\
\hline Perzborn et al. [38,39] & Rivaroxaban & PCC (Beriplex) 25 or $50 \mathrm{IU} / \mathrm{kg}$ & $\begin{array}{l}\text { Rat in vivo bleeding model } \\
\text { (mesenteric) assessing bleeding } \\
\text { time, PT, and TAT after rivaroxaban } \\
2 \mathrm{mg} / \mathrm{kg}\end{array}$ \\
\hline
\end{tabular}

rFVIIla, PCC, and fIX/fX concentrate improved TE parameters but no complete reversal was obtained.

Studies in humans receiving new oral anticoagulants

$\begin{array}{ll}\text { Eerenberg et al. } & \text { Rivaroxaban } \\ \text { [24-26] } & \text { Dabigatran }\end{array}$

Randomized controlled trial in healthy volunteers receiving either dabigatran (150 mg bid po) or rivaroxaban (20 mg bid po) $\times 2.5$ days after which PCC (or placebo) was given by IV infusion. Rivaroxaban was assessed by PT and ETP. Dabigatran was assessed by aPTT, ETP, TT, and ECT.

$\begin{array}{lll}\text { Galan et al. [49] } & \begin{array}{l}\text { Dabigatran } \\ \text { Rivaroxaban }\end{array} & \text { rFVIlla }(270 \mu \mathrm{\mu g} / \mathrm{kg}) \\ & \text { aPCC (75 IU/kg) } \\ & \text { PCC (50 IU/kg) }\end{array}$

Exvivo studies using samples from healthy individuals receiving dabigatran (150 mg po bid) or rivaroxaban (20 mg po). Samples spiked with reversal agents were tested for TG, TE, PT, INR, and aPTT. Additional studies assessed hemostasis under flow conditions.
For rivaroxaban, PCC infusion normalized PT and ETP.

For dabigatran, PCC did not correct aPTT, ETP lag time, TT, or ECT.

rFVIla and aPCC corrected the effect of rivaroxaban on PT, INR and aPTT. aPCC corrected rivaroxaban induced abnormalities in TG whereas PCC and rFVIla had modest or no effects, respectively.

aPCC corrected the effect of dabigatran on aPTT. Flow studies (resembling more closely a bleeding situation) showed that alteration induced by rivaroxaban were variably reversed by all three agents whereas only aPCCs reversed the effects of dabigatran. 
Table 3. Continued

\begin{tabular}{|c|c|c|c|c|}
\hline $\begin{array}{l}\text { Study } \\
\text { (Reference) }\end{array}$ & $\begin{array}{l}\text { Anticoagulant(s) } \\
\text { evaluated }\end{array}$ & Reversal agent(s) & $\begin{array}{l}\text { Study design/ } \\
\text { Hemostatic assessment }\end{array}$ & Outcome \\
\hline \multirow[t]{4}{*}{ Marlu et al. [33] } & Dabigatran & rFVIlla (NovoSeven; 20, 60, & \multirow{4}{*}{$\begin{array}{l}\text { Crossover randomized ex vivo } \\
\text { study in healthy donors receiving } \\
\text { either dabigatran ( } 150 \mathrm{mg} \text { po) or } \\
\text { rivaroxaban }(20 \mathrm{mg} \text { po }) \times 1 \text { dose } \\
\text { assessing TG, aPTT, and PT }\end{array}$} & \multirow{3}{*}{$\begin{array}{l}\text { For rivaroxaban PCC strongly corrected } \\
\text { ETP-AUC and modestly corrected ETP-Peak. } \\
\text { No correction of lag time. rFVIla corrected } \\
\text { only kinetic parameters. aPCC corrected all } \\
\text { parameters. }\end{array}$} \\
\hline & \multirow[t]{3}{*}{ Rivaroxaban } & and $120 \mu \mathrm{g} / \mathrm{kg}$ ) & & \\
\hline & & $\begin{array}{l}\text { aPCC (FEIBA; 20, 40, and } 80 \\
I U / k g)\end{array}$ & & \\
\hline & & $\begin{array}{l}\text { PCC (Kanokad; 12.5, 25, and } \\
50 \mathrm{IU} / \mathrm{kg})\end{array}$ & & $\begin{array}{l}\text { For dabigatran, PCC improved ETP-AUC but } \\
\text { had no effect on kinetic parameters. rFVIla } \\
\text { and aPCC corrected lag time. }\end{array}$ \\
\hline \multirow[t]{5}{*}{ Pilliteri et al. [52] } & Dabigatran & PCC (Beriplex; 12.5, 25, 50, & \multirow{5}{*}{$\begin{array}{l}\text { Crossover randomized ex vivo } \\
\text { study in health donors receiving } \\
\text { either dabigatran ( } 150 \mathrm{mg} \text { po) or } \\
\text { rivaroxaban ( } 20 \mathrm{mg} \mathrm{po} \text { ) } \times 1 \text { dose } \\
\text { assessing TG, aPTT, and PT, TT, } \\
\text { rivaroxaban, and dabigatran levels } \\
\text { and ECT. }\end{array}$} & \multirow{5}{*}{$\begin{array}{l}\text { aPCC and rFVIla showed reversal of both } \\
\text { anticoagulants assessed by TG. Cofact } \\
\text { showed improvement on TG but Beriplex } \\
\text { did not. }\end{array}$} \\
\hline & \multirow[t]{4}{*}{ Rivaroxaban } & & & \\
\hline & & $\begin{array}{l}\text { PCC (Cofact; 12.5, 25, 50, and } \\
100 \text { IU/kg) }\end{array}$ & & \\
\hline & & $\begin{array}{l}\text { aPCC (FEIBA; } 20,40,80 \text {, and } \\
160 \text { IU/kg) }\end{array}$ & & \\
\hline & & $\begin{array}{l}\text { rFVIla (NovoSeven; 75, } 125 \\
250 \text { and } 500 \mu \mathrm{g} / \mathrm{kg} \text { ) }\end{array}$ & & \\
\hline
\end{tabular}

anti-fXa, anti-activated factor X activity; aPCC, activated prothrombinase complex concentrate; aPTT, activated partial thromboplastin time; AUC, area under the curve; bid, twice daily; BT, bleeding time; ECT, ecarin clotting time; ETP, endogenous thrombin potential; FFP, fresh frozen plasma; flX, coagulation factor IX; $\mathrm{fX}$, coagulation factor X; INR, international normalized ratio; IV, intravenous; PCC, prothrombin complex concentrate; po, by mouth; PT prothrombin time; rFVIIA, recombinant activated factor VII; TAT, thrombin-antithrombin complex; TE, thromboelastography; TG, thrombin generation assay; TT, thrombin time.

Table 4. Pro-hemostatic agents and their potential role on the reversal of new oral anticoagulants

\begin{tabular}{|c|c|c|c|}
\hline Agent & $\begin{array}{l}\text { Doses tested in } \\
\text { human studies }\end{array}$ & Dabigatran etexilate & Rivaroxaban or Apixaban ${ }^{a}$ \\
\hline $\begin{array}{l}\text { Four-factor prothrombinase complex concentrate } \\
\text { (Beriplex, Octaplex) }\end{array}$ & 12.5 to $100 \mathrm{lU} / \mathrm{kg}$ & Possibly beneficial & Probably beneficial \\
\hline $\begin{array}{l}\text { Activated four-factor prothrombinase complex concentrate } \\
\text { (FEIBA) }\end{array}$ & 20 to $160 \mathrm{lU} / \mathrm{kg}$ & Probably beneficial & Probably beneficial \\
\hline Recombinant activated factor VII (Novoseven, Niastase) & 20 to $500 \mu \mathrm{g} / \mathrm{kg})$ & Possibly beneficial & Possibly beneficial \\
\hline Fresh frozen plasma & Not applicable & Probably ineffective & Probably ineffective \\
\hline Cryoprecipitate & Not applicable & Probably ineffective & Probably ineffective \\
\hline Three-factor prothrombinase complex concentrate & No data available & No available evidence & No available evidence \\
\hline
\end{tabular}

No study has assessed the clinical effect of these agents in patients with active bleeding events. The possible role of these agents is based on animal studies and human studies evaluating surrogate coagulation markers. All evidence should be considered low quality and the use of these agents should follow a careful consideration of risks and benefits. a No study has assessed the clinical effect of these agents in patients receiving apixaban. The possible role of these agents is theoretical and is based on extrapolation of evidence available for patients receiving rivaroxaban. ${ }^{\mathrm{b}}$ There is no available evidence regarding efficacy or safety. Adapted from $[23,26,29,30,33,39,41,43,46]$.

the diversity of experimental models and assessments used and because of the lack of conclusive evidence relating the correction of laboratory parameters evaluating the hemostatic system with the effect on actual bleeding events.

Given the lack of effective reversal agents, several new agents are currently being evaluated, the most promising of which are the monoclonal humanized anti-dabigatran antibody and Fab fragment and the r-Antidote
(PRT064445) for direct Xa inhibitors. To the best of our knowledge, the latter drug is the only one that has achieved clinical development and is currently being evaluated in a phase II study, the results of which could be expected in late 2014. Further studies are urgently needed to elucidate the clinical effect of the currently available and prospective agents on patients with actual bleeding events and in particular on vital and functional outcomes. 


\section{Abbreviations}

aPCC, activated prothrombinase complex concentrate; aPTT, activated partial thromboplastin time; $\mathrm{CrCl}$, creatinine clearance; $\mathrm{ECT}$, ecarin clotting time; ETP, endogenous thrombin potential; FXa, activated factor $\mathrm{X}$; NOAC, new oral anticoagulant; PCC, prothrombinase complex concentrate; PT, prothrombin time; rFVIla, recombinant activated factor VII; $T$, thrombin time.

\section{Competing interests}

AL-L has received honoraria from Pfizer Inc (New York, NY, USA), Leo Pharma (Ballerup, Denmark), Sanofi-Aventis (Paris, France), and Boehringer Ingelheim (Ingelheim, Germany). ESL has received speaking honoraria from Bayer (Leverkusen, Germany) and Boehringer Ingelheim. JD has been a consultant, in the past 10 years, for AGEN Biomedical (Melbourne, Australia), AstraZeneca (London, UK), Bayer, Boehringer Ingelheim, Bristol-Myers Squibb Company (Princeton, NJ, USA), Ortho-McNeil Pharmaceutical (Raritan, NJ, USA), Pfizer Inc, and Sanofi-Aventis.

\section{Authors' contributions}

AL-L abstracted data and contributed to searching the literature and selecting studies for inclusion, checking data for accuracy, and writing the manuscript. ESL and JD contributed to searching the literature and selecting studies for inclusion, checking data for accuracy, and writing the manuscript.

\section{Author details}

'Department of Medicine, University of Western Ontario, 800 Commissioners Rd. East, Room A2-401, London, ON, Canada, N6A 5W9. ²Department of Epidemiology and Biostatistics, University of Western Ontario, 800 Commissioners Rd. East, Room A2-401, London, ON, Canada, N6A 5W9. ${ }^{3}$ Division of Emergency Medicine, Department of Family Medicine University of Calgary, Unit 1633, 163214 Avenue NW, Calgary, AB, Canada, T2N 1 M7. ${ }^{4}$ Department of Medicine, Division of Hematology and Thromboembolism, McMaster University, Hamilton, 50 Charlton Avenue East, Hamilton, ON Canada, L8N 4A6.

Published: 17 June 2013

\section{References}

1. U.S. Food and Drug Administration: FDA News release. FDA expands use of Xarelto to treat, reduce recurrence of blood clots [http://www.fda.gov/ NewsEvents/Newsroom/PressAnnouncements/ucm326654.htm].

2. Stangier J, Rathgen K, Stahle H, Gansser D, Roth W: The pharmacokinetics, pharmacodynamics and tolerability of dabigatran etexilate, a new oral direct thrombin inhibitor, in healthy male subjects. Br J Clin Pharmacol 2007, 64:292-303.

3. Kubitza D, Becka M, Voith B, Zuehlsdorf M, Wensing G: Safety, pharmacodynamics, and pharmacokinetics of single doses of BAY 59-7939, an oral, direct factor Xa inhibitor. Clin Pharmacol Ther 2005, 78:412-421.

4. The Thrombosis Interest Group of Canada homepage [http://www.tigc.org/].

5. Mayer SA, Brun NC, Begtrup K, Broderick J, Davis S, Diringer MN, Skolnick BE, Steiner T: Efficacy and safety of recombinant activated factor VII for acute intracerebral hemorrhage. N Engl J Med 2008, 358:2127-2137.

6. Yank V, Tuohy CV, Logan AC, Bravata DM, Staudenmayer K, Eisenhut R, Sundaram V, McMahon D, Olkin I, McDonald KM, Owens DK, Stafford RS: Systematic review: benefits and harms of in-hospital use of recombinant factor VIla for off-label indications. Ann Intern Med 2011, 154:529-540.

7. Dutton RP, Parr M, Tortella BJ, Champion HR, Bernard GR, Boffard K, Bouillon B, Croce MA, Dimsits J, Holcomb JB, Leppaniemi A, Vincent JL, Hauser CJ; CONTROL Study Group: Recombinant activated factor VII safety in trauma patients: results from the CONTROL trial. J Trauma 2011, 71:12-19.

8. Majeed A, Eelde A, Agren A, Schulman S, Holmstrom M: Thromboembolic safety and efficacy of prothrombin complex concentrates in the emergency reversal of warfarin coagulopathy. Thromb Res 2012, 129:146-151.

9. Hsia CC, Chin-Yee IH, McAlister VC: Use of recombinant activated factor VII in patients without hemophilia: a meta-analysis of randomized control trials. Ann Surg 2008, 248:61-68.

10. Dentali F, Marchesi C, Pierfranceschi MG, Crowther M, Garcia D, Hylek E, Witt DM, Clark NP, Squizzato A, Imberti D, Ageno W: Safety of prothrombin complex concentrates for rapid anticoagulation reversal of vitamin $\mathrm{K}$ antagonists. A meta-analysis. Thromb Haemost 2011, 106:429-438.

11. Lu G, Luan P, Hollenbach SJ, Abe K, Deguzman FR, Siu G, Hutchaleelaha A, Inagaki M, Conley PB, Phillips DR, Sinha U: Reconstructed recombinant factor $\mathrm{Xa}$ as an antidote to reverse anticoagulation by factor Xa inhibitors. J Thromb Haemost 2009, 7: Abstract OC-TH-107.

12. Lu G, Deguzman FR, Karbarz MJ, Hollenbach SJ, Conley PB, Hutchaleelaha A, Sinha U: Reversal of rivaroxaban mediated anticoagulation in animal models by a recombinant antidote protein (r-Antidote, PRT064445). Eur Heart J 2011, 32: Abstract 3715.

13. Van Ryn J, Litzenburger T, Waterman A, Canada K, Hauel N, Sarko C, Kroe-Barrett R, Singh S, Park J: An antibody selective to dabigatran safely neutralizes both dabigatran-induced anticoagulant and bleeding activity in in vitro and in vivo models. J Thromb Haemost 2011, 9:110. Abstract P-MO-166.

14. Carrier M, Le Gal Gg, Wells PS, Rodger MA: Systematic review: case-fatality rates of recurrent venous thromboembolism and major bleeding events among patients treated for venous thromboembolism. Ann Intern Med 2010, 152:578-589.

15. Linkins LA, Choi PT, Douketis JD: Clinical impact of bleeding in patients taking oral anticoagulant therapy for venous thromboembolism: a meta-analysis. Ann Intern Med 2003, 139:893-900.

16. Patel MR, Mahaffey KW, Garg J, Pan G, Singer DE, Hacke W, Breithardt G, Halperin JL, Hankey GJ, Piccini JP, Becker RC, Nessel CC, Paolini JF, Berkowitz SD, Fox KA, Califf RM; ROCKET AF Investigators: Rivaroxaban versus warfarin in nonvalvular atrial fibrillation. N Engl J Med 2011, 365:883-891.

17. Kubitza D, Becka M, Wensing G, Voith B, Zuehlsdorf M: Safety, pharmacodynamics, and pharmacokinetics of BAY 59-7939-an oral, direct factor Xa inhibitor- after multiple dosing in healthy male subjects. Eur $J$ Clin Pharmacol 2005, 61:873-880.

18. Kubitza D, Becka M, Mueck W, Halabi A, Maatouk H, Klause N, Lufft V, Wand DD, Philipp T, Bruck H: Effects of renal impairment on the pharmacokinetics, pharmacodynamics and safety of rivaroxaban, an oral, direct Factor Xa inhibitor. Br J Clin Pharmacol 2010, 70:703-712.

19. Stangier J, Rathgen K, Stähle H, Mazur D: Influence of renal impairment on the pharmacokinetics and pharmacodynamics of oral dabigatran etexilate: an open-label, parallel-group, single-centre study. Clin Pharmacokinet 2010, 49:259-268.

20. Van Ryn J, Neubauer M, Flieg R, Krause B, Storr M, Hauel N, Priepke H, Clemens A: Successful removal of dabigatran in flowing blood with an activated charcoal hemoperfusion column in an in vitro test system. Pathophysiol Haemost Thromb 2010, 37: Abstract P 485.

21. Lindahl TL, Baghaei F, Blixter IF, Gustafsson KM, Stigendal L, Sten-Linder M, Strandberg K, Hillarp A; Expert Group on Coagulation of the External Quality Assurance in Laboratory Medicine in Sweden: Effects of the oral, direct thrombin inhibitor dabigatran on five common coagulation assays. Thromb Haemost 2011, 105:371-378.

22. Majeed A, Hwang H, Bruggink ED, Connolly S, Eikelboom JW, Ezekowitz M, Wallentin L, Yusuf S, Schulman S: Management and outcomes of major bleeding on dabigatran or warfarin. Blood 2012, 120: Abstract 19.

23. Chan HHW, Atkinson HM, Goncharenko M, Berry LR, Chan AKC: Reversal of dabigatran using recombinant activated factor vii and activated prothrombin complex concentrates in thromboelastography assay. J Thromb Haemost 2011, 9:576-577. Abstract P-WE-180.

24. Eerenberg ES, Sijpkens MK, Kamphuisen PW, Meijers JCM, Levi M: Prothrombin complex concentrate reverses the anticoagulant effect of rivaroxaban in healthy volunteers. Blood 2010, 116: Abstract 1094.

25. Eerenberg ES, Kamphuisen PW, Sijpkens MK, Meijers JCM, Buller HR, Levi M: Reversal of rivaroxaban and dabigatran by prothrombin complex concentrate: A randomized, placebo-controlled, cross-over study in healthy subjects. J Thromb Haemost 2011, 9:657. Abstract P-WE-435.

26. Eerenberg ES, Kamphuisen PW, Sijpkens MK, Meijers JC, Buller HR, Levi M: Reversal of rivaroxaban and dabigatran by prothrombin complex concentrate: A randomized, placebo-controlled, crossover study in healthy subjects. Circulation 2011, 124:1573-1579.

27. Godier A, Miclot A, Le BB, Durand M, Lecompte T, Samama CM: Evaluation of prothrombin complex concentrate, recombinant activated factor VII and fibrinogen concentrate to reverse rivaroxaban in a rabbit model of bleeding and thrombosis. Eur J Anaesthesiol 2011, 28:87. Abstract 6AP3-8.

28. Godier A, Miclot A, Le BB, Durand M, Emmerich J, Fischer AM, Lecompte T, Samama CM: Evaluation of prothrombin complex concentrate, recombinant activated factor VII and fibrinogen concentrate to reverse 
rivaroxaban in a rabbit model. J Thromb Haemost 2011, 9:388. Abstract P-TU-253.

29. Godier A, Miclot A, Le BB, Durand M, Fischer A-M, Emmerich J, MarchandLeroux C, Lecompte T, Samama C-M: Evaluation of prothrombin complex concentrate and recombinant activated factor VII to reverse rivaroxaban in a rabbit model. Anesthesiology 2012, 116:94-102

30. Gruber A, Marzec UM, Buetehorn U, Hanson SR, Perzborn E: Activated factor VII and activated prothrombin complex for reversal of the antihaemostatic effects of rivaroxaban in primates. Br J Haematol 2009, 145: Abstract 80.

31. Gruber A, Marzec UM, Buetehorn U, Hanson S, Perzborn E: Reversal of the antihaemostatic effects of rivaroxaban by activated factor VII and activated prothrombin complex in primates. Haematologica 2009, 94:June. Abstract 0449 .

32. Keller MK, Langer E, Ziemer S, Von HC: RIVACAPT (RIVAroxaban Coagulation Antagonisation Pilot Trial). Hamostaseologie 2012, 32:A13. Abstract ED10-7.

33. Marlu R, Hodaj E, Paris A, Albaladejo P, Crackowski JL, Pernod G: Effect of non-specific reversal agents on anticoagulant activity of dabigatran and rivaroxaban. A randomised crossover ex vivo study in healthy volunteers. Thromb Haemost 2012, 108:217-224

34. Martin A-C, Le BB, Lecompte T, Dizier B, Emmerich J, Fischer A-M, Samama C-M, Godier A: Evaluation of prothrombin complex concentrate, recombinant activated factor $\mathrm{VII}$ and fibrinogen concentrate to reverse apixaban in a rabbit model. Cardiovasc Res 2012, 93:S73. Abstract P364.

35. Martin A-C, Le-Bonniec B, Lecompte T, Fischer A-M, Emmerich J, Samama C-M, Godier A, Val De GH: Evaluation of recombinant activated factor VII prothrombin complex concentrate and fibrinogen concentrate to reverse apixaban in a rabbit model. J Am Coll Cardio/ 2012, 59:E573.

36. Martin A-C, Le-Bonniec B, Lecompte T, Fischer A-M, Emmerich J, Samama C-M, Godier A: Evaluation of recombinant activated factor VII, prothrombin complex concentrate and fibrinogen concentrate to reverse apixaban in a rabbit model. Eur Heart J 2012, 33:496. Abstract 2963.

37. Olesen JB, Christiansen K, Ingerslev J, Sorensen B, Hvas A: Haemostatic response to in vitro addition of recombinant factor Vila, prothrombin complex concentrate, or concentrate of Factor IX/X in blood spiked with a direct Xa inhibitor. J Thromb Haemost 2009, 7: Abstract PP-MO-386.

38. Perzborn E, Trabandt A, Selbach K, Tinel H: Prothrombin complex concentrate reverses the effects of high-dose rivaroxaban in rats. Hamostaseologie 2010, 30:A103. Abstract P16-01.

39. Perzborn E, Trabandt A, Selbach K, Tinel H: Prothrombin complex concentrate reverses the effects of high-dose rivaroxaban in rats. Pathophysiol Haemost Thromb 2010, 37: Abstract OC 251

40. Pragst I, Zeitler SH, Doerr B, Kaspereit FJ, Herzog E, Dickneite G, van Ryn J: Reversal of dabigatran anticoagulation by prothrombin complex concentrate (Beriplex P/N) in a rabbit model. J Thromb Haemost 2012, 10:1841-1848

41. Van Ryn J, Ruehl D, Priepke H, Hauel N, Wienen W: Reversibility of the anticoagulant effect of high doses of the direct thrombin inhibitor dabigatran, by recombinant factor VIla or activated prothrombin complex concentrate. Haematologica 2008, 93: Abstract 0370.

42. Van Ryn J, Neubauer M, Flieg R, Krause B, Storr M, Hauel N, Priepke H, Clemens A: Successful removal of dabigatran in flowing blood with an activated charcoal hemoperfusion column in an in vitro test system. Haematologica 2010, 95:293. Abstract 0700.

43. Van Ryn J, Dorr B, Kaspereit F, Krege W, Zeitler S, Pragst I: Beriplex P/N reverses bleeding in an acute renal injury model after dabigatran overdose in rabbits. Pathophysiol Haemost Thromb 2010, 37: Abstract P 486

44. Van Ryn J, Schurer J, Kink-Eiband M, Clemens A: The successful reversal of dabigatran-induced bleeding by coagulation factor concentrates in a rat tail bleeding model do not correlate with ex vivo markers of anticoagulation. Blood 2011, 118: Abstract 2316

45. Van Ryn J, Litzenburger T, Waterman A, Canada K, Hauel N, Sarko C, KroeBarrett $R$, Singh S, Park J: Dabigatran anticoagulant activity is neutralized by an antibody selective to dabigatran in in vitro and in vivo models. J Am Coll Cardiol 2011, 57:E1130.

46. Zhou W, Schwarting S, Illanes S, Liesz A, Middelhoff M, Zorn M, Bendszus M, Heiland S, van Ryn J, Veltkamp R: Hemostatic therapy in experimental intracerebral hemorrhage associated with the direct thrombin inhibitor dabigatran. Stroke 2011, 42:3594-3599.

47. Lloyd J, Feldman P, Ryan L: In vitro reversal of the direct Xa inhibitor rivaroxaban using high-purity factor $X$ concentrate (factor X). Haemophilia 2012, 18:33. Abstract PO-TU-033.
48. Toth J, Gandolfi R, Van Ryn J, Dursema H, Isler J, Coble K, Burke J, Lalovic B, Olson S: Reversal of dabigatran's anticoagulant activity in the monkey by a specific antidote and pharmacokinetic and pharmacodynamic modeling. Blood 2012, 120:Abstract 22.

49. Galan A, Arellano-Rodrigo E, Sanz V, Molina P, Reverter JC, Carne X, Villalta J, Tassies D, Diaz-Ricart M, Escolar G: Reversal of the antithrombotic action of rivaroxaban and dabigatran: a clinical study in healthy volunteers. Blood 2012, 120:Abstract 2261.

50. Escolar G, Arellano-Rodrigo E, Reverter JC, Villalta J, Sanz V, Molina P, Diaz Ricart M, Galan A: Coagulation factor concentrates restore alterations in hemostasis induced by a high dose of apixaban: studies in vitro with circulating human blood. Blood 2012, 120:Abstract 2263.

51. Lange J, Thiel C, Thiel K, Klingert W, Klingert K, Konigsrainer A, Formella S, Clemens A, Van Ryn J, Schenk M: Acceleration of dabigatran elimination by activated charcoal perfusion and hemodialysis in a pig model. Blood 2012, 120:Abstract 2272

52. Pillitteri D, Pilgrimm-Thorp A, Krause M, Scholz T, Schwerdtfeger R, Behrendt T, Kirchmaier C: Antidotal effects of non-specific reversal agents on anticoagulant-induced inhibition of thrombin generation. Blood 2012, 120:Abstract 2273

53. Hollenbach SJ, Lu G, Tan S, Lee G, Hutchaleelaha A, Inagaki M, Sinha U: PRT064445 but not recombinant Fviia reverses rivaroxaban induced anticoagulation as measured by reduction in blood loss in a rabbit liver laceration model. Blood 2012, 120:Abstract 3414

54. Van Ryn J, Litzenburger T, Gan G, Coble K, Schurer J: In vitro characterization pharmacokinetics and reversal of supratherapeutic doses of dabigatraninduced bleeding in rats by a specific antibody fragment antidote to dabigatran. Blood 2012, 120:Abstract 3418

55. Hoffman M, Volovyk Z, Monroe D: Partial reversal of dabigatran effect by a prothrombin complex concentrate in a model of thrombin generation. Blood 2012, 120:Abstract 3420.

56. Van Ryn J, Stangier J, Haertter S, Liesenfeld KH, Wienen W, Feuring M, Clemens A: Dabigatran etexilate - a novel, reversible, oral direct thrombin inhibitor: interpretation of coagulation assays and reversal of anticoagulant activity. Thromb Haemost 2010, 103:1116-1127.

57. Bayer Inc.: Xarelto (Rivaroxaban) Product Monograph. Toronto, Ontario: 2012.

58. Boehringer Ingelheim: Pradaxa (Dabigatran Etexilate) Product Monograph Burlington, Ontario: 2012

59. Pfizer Inc., Bristol-Myers Squibb: Eliquis (apixaban) Product Monograph. Kirkland, Quebec; Montreal, Quebec: 2011.

60. Frost C, Wang J, Nepal S, Schuster A, Barrett YC, Mosqueda-Garcia R, Reeves RA, Lacreta F: Apixaban, an oral, direct factor Xa inhibitor: single-dose safety, pharmacokinetics, pharmacodynamics and food effect in healthy subjects. Br J Clin Pharmacol 2013, 75:476-487.

61. Raghavan N, Frost CE, Yu Z, He K, Zhang H, Humphreys WG, Pinto D, Chen S, Bonacorsi S, Wong PC, Zhang D: Apixaban metabolism and pharmacokinetics after oral administration to humans. Drug Metab Dispos 2009, 37:74-81.

62. Hillarp A, Baghaei F, Fagerberg Blixter I, Gustafsson KM, Stigendal L, Sten-Linder M, Strandberg K, Lindahl TL: Effects of the oral, direct factor Xa inhibitor rivaroxaban on commonly used coagulation assays. J Thromb Haemost 2011, 9:133-139.

63. Douxfils J, Mullier F, Robert S, Chatelain C, Chatelain B, Dogne JM: Impact of dabigatran on a large panel of routine or specific coagulation assays. Laboratory recommendations for monitoring of dabigatran etexilate. Thromb Haemost 2012, 107:985-997.

64. Stangier J, Feuring M: Using the HEMOCLOT direct thrombin inhibitor assay to determine plasma concentrations of dabigatran. Blood Coagul Fibrinolysis 2012, 23:138-143.65. DeRemer CE, Gujral JS, Thornton JW, Sorrentino RA: Dabigatran falsely elevates point of care international normalized ratio results. Am J Med 2011, 124:e5-e6.

66. Baruch L, Sherman O: Potential inaccuracy of point-of-care INR in dabigatran-treated patients. Ann Pharmacother 2011, 45:e40.

67. Freyburger G, Macouillard G, Labrouche S, Sztark F: Coagulation parameters in patients receiving dabigatran etexilate or rivaroxaban: two observational studies in patients undergoing total hip or total knee replacement. Thromb Res 2011, 127:457-465.

68. Samama MM, Martinoli JL, LeFlem L, Guinet C, Plu-Bureau, Depasse F, Perzborn E: Assessment of laboratory assays to measure rivaroxaban - an oral, direct factor Xa inhibitor. Thromb Haemost 2010, 103:815-825. 
69. Wong PC, Crain EJ, Watson CA, Xin B: Favorable therapeutic index of the direct factor Xa inhibitors, apixaban and rivaroxaban, compared with the thrombin inhibitor dabigatran in rabbits. J Thromb Haemost 2009, 7:1313-1320. doi:10.1186/cc12592

Cite this article as: Lazo-Langner A, et al: Clinical review: Clinical management of new oral anticoagulants: a structured review with emphasis on the reversal of bleeding complications. Critical Care 2013, 17:230. 